\title{
Role of Attitude and Entrepreneurship Education towards Entrepreneurial Orientation among Business Students of Bhutan
}

\author{
Shad Ahmad Khan, Purna Prasad Sharma, Prabha Thoudam
}

\begin{abstract}
Purpose-The motivation and objective to write this is to understand the role of attitude and entrepreneurial education on students of Bhutan in taking entrepreneurship as a career.

Design/methodology/approach -Grounded on theory of reasoned action, entrepreneurship education theories/studies, didactic theory and other prior studies, the purpose of this study is to propose a research model to further explore role attitude and entrepreneurial education on entrepreneurship orientation. The governing theory this study is "Attitude of an Individual is influenced by Entrepreneurship Education that leads him to take entrepreneurship as a career". Data Collected from 253 respondents who were business students of the only premier business college of Bhutan.

Findings-The derived results in this work indicates that both attitude and entrepreneurship education are positively related to entrepreneurship orientation. However, the relationship between attitude and entrepreneurship orientation is found to be stronger than that of entrepreneurship education and entrepreneurship orientation. The regression weights also second this relationship. SEM analysis is conducted to analyze the factors, and majority of the variables were retained and had significance to the measure of the respective construct. In mediation analysis, partial mediation was identified on the part of Entrepreneurship Education.
\end{abstract}

Originality/Value-The practical evidence found in this study is supportive of the relationship between perception-attitude and entrepreneurship education on students of Bhutan in context of entrepreneurship orientation. The findings provided important practical as well as theoretical implications for the business schools.

Keywords : Entrepreneurship, Education, Attitude, Orientation.

\section{INTRODUCTION}

Entrepreneurship is crucial for any economy. For the long term prosperity of any country, Entrepreneurs play a major role in it. They not only create an employment for themselves but also are responsible for the employment of others. For any country it is important to promote entrepreneurship, if it

Revised Manuscript Received on October 15, 2019.

* Correspondence Author

Dr. Shad Ahmad Khan, Assistant Professor, College of Business, University of Buraimi, Sultanate of Oman

Dr. Purna Prasad Sharma, Assistant Professor, Gedu College of Business Studies, Royal University of Bhutan, Bhutan

Dr. Prabha Thoudam, Assistant Professor, College of Business, University of Buraimi, Sultanate of Oman wishes to achieve sustainability and reliability. For an economy Entrepreneurship is an important driver to shift the burden of job creation from the government to the individuals. Kingdom of Bhutan being a small country both in terms of size and population has been functioning as a mixed economy, but the major share of GDP comes from the public sector. This is evident enough to suggest the need for growth of Entrepreneurs in the Country. There have been sufficient researches conducted that shows that entrepreneurs can be created by imparting entrepreneurial education catering to specialized needs of potential entrepreneurs. Business Schools around the globe are such instructions where entrepreneurship is offered as programme and thus are the frontiers of imparting entrepreneurial education. Many researchers have suggested that in the process of opting Entrepreneurship as a career, attitude of individuals is crucial. The main objective of such education is to create future entrepreneurs or create orientation towards entrepreneurship. Further, many researchers have suggested that attitude of individuals also play an important role in opting Entrepreneurship as a career. Gedu College of Business Studies (GCBS) is the only premier government business college of Bhutan offering variety of programmes in Business Management including entrepreneurship development (known as EDP). By every aspect GCBS is the only specialized institution for business management in Bhutan and therefore, the study conducted in Gedu College can be generalized to the business students of the country. EDP as a specialization was introduced in the college in the academic year 2013, with an objective of creating future entrepreneurs. This specialization was well received in the initial days but suffered a decline in the interested applicantsin the subsequent years. In the academic year 2016-2017 the specialization suffered a zero intake, as the students gave more preference to the specializations like Accounting, Finance, Marketing and Human Resource Management. This perception of students towards entrepreneurship as a career option is alarming. GCBS also has instances where the students from other specializations have taken entrepreneurship as a career and are successful in their fields. To account all these issues the present studies the role of Attitude and Entrepreneurship Education towards Entrepreneurial Orientation: A Study on Business Students of Bhutan, examines the relationship between Attitude and Entrepreneurship Education and evaluates its effect on Entrepreneurship Orientation.

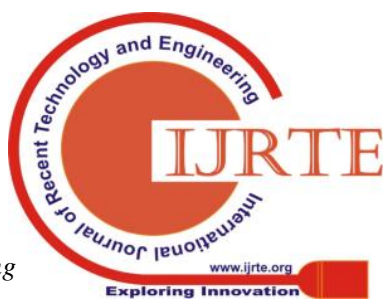




\section{REVIEW OF LITERATURES}

Entrepreneurship has no unified definition as it is viewed from multi-dimensional aspect by different people. In the words of Hisrich and Shepherd (2008) Entrepreneurship can be understood as a system which is creating new product or service with value and devotion of time and effort,cumulating together with finance, social and psychological risk. This effort and risk shall result in a financial independence and self-satisfaction. Shane (2010) explains entrepreneurship as an action, where an individual is innovative, achieves financial gains and shows business smartness by delivering valuable products and services. For some it is a creative talent like of an artist, for establishing and operating a business enterprise in a sustainable and profitable way, Teshome (2014), Odunaike and Amoda (2013). In the same year Global Entrepreneurship Research Association (GERA) defined it as "any attempt at new business or new venture creation, such as self-employment, a new business organization, or the expansion of an existing business, by an individual, a team of individuals, or an established business" (GERA, 2013). By definitions one can understand and infer that entrepreneurship is innovative and entrepreneur is audacious and is able to foresee opportunities where others may see risk. But eventually this is a strategic move to reduce unemployment and advancing financial and economic development by exploiting trade opportunities. This adopted the definition GERA (2013) definition for further study.

\subsection{Entrepreneurship Education}

Entrepreneurship requires consistent passion and desire solutions. Overall effect of the entrepreneurship education is identified as most critical factor which would help the youth to develop and adopt entrepreneurial approach (Gorman et al., 1997; Kourilsky and Walstad, 1998).Entrepreneurship Education in schools and colleges are a part of academic curricula (i.e., curriculum, pedagogy, lecturer/teacher encouragement) and non-academic activities (co-curricular and ability to interact in multiple languages) that the student participate in. The entrepreneurial education is a curriculum promoting entrepreneurship as a career and skill development through training to develop a business and be able to grow it (Vesper, 1983; Bechard \& Toulouse, 1998). It is the learning and knowledge acquired with business like attitude and skill enhancement which enables the person to face business challenges however they are, and take wise decisions to anticipate new opportunities in economic trends and in regular life. Several publications can be found linking the favorable relationship of entrepreneurship attitudeand education (Brenner, et al 1991: Fleming, 1994: Kolveried, 1996). Having Entrepreneurship attitude and education is quite useful in general life as much as it is in business. It prepares an individual to initiate a venture by applying the learning and knowledge with the help of relevant skills to improve the efficiency and drive of the individual to effectively become an entrepreneur (Gorman et al., 1997). The attitude of pupils perusing entrepreneurship studies is influenced by the drive to grow interest and improve performance and growth in entrepreneurship education. Success and failures are part of entrepreneurship journey and for implementing and creating new creative ideas and

the society is expected to embrace the same with open mind According Eurydice, (2016). It can be deduced that optimistic approach is needed towards the educational intuitions and investors, media and community to support the today's entrepreneurs for better tomorrow.

\subsection{Attitude}

Different definitions from various authors have been taken in attempt to frame the clear portrait of attitude. Attitude is defined as the vantage point, a way of thinking, visualizing and reacting to it. Perception is the ability of an individual to see, hear or become aware of something through the senses. Student's attitude is an important factor in framing policies and program on employment and entrepreneurship in the country. This section focuses on the perception and attitude of the students on taking entrepreneurship as their major course and in employment scenario, taking entrepreneurship as a career choice in the country. Stakeholders such as parents, teachers, lecturers, principal and the local government officials play an important role in developing an entrepreneurial mindset among the students says Utha (2016). Hence, their views are also taken to supplement students' views on the current employment and entrepreneurship scenario in the country. Simpson and Oliver (1990) presented attitude as and emotional drift depending at certain circumstanceslaffairs, situations, people, positionsllocations, happeningslevents or ideas. Kennedy and Peterman (2003) examine the effect of participation in an entrepreneurship education program on perceptions of the desirability and feasibility of starting a business and it is seen that the degree of change in perceptions is related to the Positiveness of prior experience in the entrepreneurial education program.

Katz (2003) defines attitude in his terms as a tendency of a person to assess and evaluate signslsymbols, aspects or substance in the world, being perceived in supportive or unsupportive way. He also quoted on attitude two directional thoughts, first curtailing logical and rational thinking person/student and second provoking logical and rational thinking person/student. He also quoted the psychological behaviors of ease or resentment towards change in attitude depends on how someone behaves and acts, varying from individual to individual. These behaviors can be categorized as the defending ones ego, being flexible, knowledge and value expression. The above studies show that students those who are taking entrepreneurship course are mainly with their intention to become entrepreneur based on their attitude. This attitude and perception is developed because of the environment (internal \& external) in which he has lived. Many researchers have advocated studying attitude and perception as a separate factor.

\subsection{Entrepreneurial Orientation}

It is clarified by Wiklund and Shepherd (2003) that students performance in entrepreneurship mostly depends up-on the entrepreneurial Strategic Orientation (EO), without being influenced by internal characteristics. 
They also highlighting the important characteristics of EO for the way firms are structured. The outcomes indicate that knowledge of identification opportunities and using then to self-advantage are definitely related to the organization performance and enhancing the EO, from students and employees. According to Khan (2017) entrepreneurs are oriented through combination of both internal and external factors. Further Blanch flower (2000) claimed that the self-employment rate is in negative for most countries. It further stated that the probability of being self-employed is higher among men than women and rises with age and also the people who are self-employed are satisfied higher than others. Shepherd and Douglas (2002) defined Entrepreneurs as terms of the strengths and weakness of these dimensions where the strength of desires to become self-employed was considerably connected to the respondents' tolerance for risk and their preference for independence.

As it can be seen from the above studies that the basic motive of offering the entrepreneurship education is to create self-employment by way of establishing entrepreneurial ventures, it can be assumed that the students opting for entrepreneurship education have an orientation to start their own enterprise. Thus, entrepreneurial orientation i.e. willingness to start enterprise is another area to be explored.

\section{PARADIGM THEORY, MODEL AND HYPOTHESIS}

\subsection{Paradigm Theory}

The present study is based on the belief that education can affect the perception of the individuals and can act as a mediator for him to take entrepreneurship as a career. The entrepreneurship as a career has been referred as entrepreneurship orientation. The paradigm theory governing this study is "Perception and Attitude of an Individual is influenced by Entrepreneurship Education that leads him to take entrepreneurship as a career". The same is given proposed in the form of a research model as given under Figure 1.

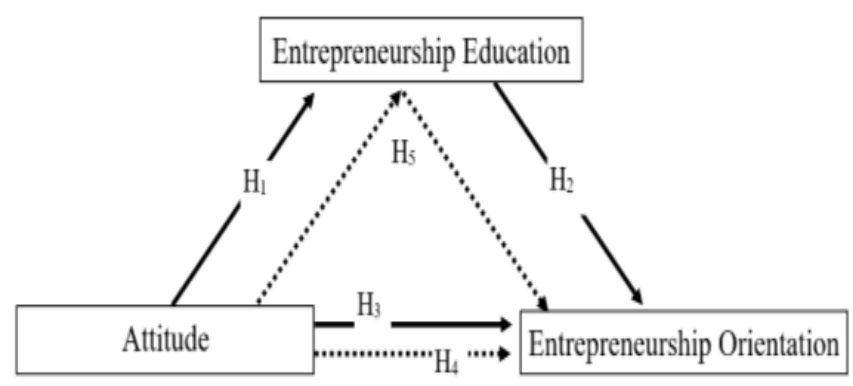

Figure 1. Research Model

Based on Figure 1, following hypotheses has been proposed

H1 Positive attitude towards entrepreneurship leads to entrepreneurship education
H2 Entrepreneurship education influences the person to take up Entrepreneurship as a career

H3 Positive attitude towards entrepreneurship leads to Entrepreneurship Orientation

H4 Attitude towards entrepreneurship will lead to Entrepreneurship Orientation directly

H5 Entrepreneurship Education is a mediator between Perception and Attitude and Entrepreneurship Orientation

\section{METHODOLOGY}

Derived from the hypotheses above, this study defined each variable operationally within tentative model shown in Figure 1.

This study is based on descriptive research conducted on students of Gedu College of Business Studies on account of sudden fall in number of students opting entrepreneurship majors. As it can be clearly stated from the statement above, the population for the study is the students of Gedu College of Business Studies. Further this study has concentrated on the students who are already in their respective specialization (majors) i.e. exclusion of common foundation students from the population. To put it into statement, population for this study is the GCBS students of second and third year of their graduation.

\subsection{Measures of the constructs:}

Concepts used in this study to measure the area of entrepreneurship, were developed based on earlier studies and models in this arena, perception-attitude and entrepreneurial trainings-education. Measures for Entrepreneurship education were adopted from studies conducted by Vesper, (1983); Bechard \& Toulouse, (1998), Brenner, et al (1991): Fleming, (1994): Kolveried, (1996), Gorman et al., (1997), EU (2009). The mean scores of the 11 statements are assumed to be Entrepreneurship Education (EE). The items for EE have been codified from EE1 to EE11.

Similarly, 16 constructs to measures perception and attitude were extracted from the studies by Ajzen and Fishbein (1980); Ajzen (1990); Simpson and Oliver (1990), Roberts (1986). The mean scores of the 16 statements are assumed to be Perception and Attitude and is coded as PA. The items for PA have been codified from PA1 to PA16. To measure entrepreneurial orientation (EO) prior study by Shephered and Johan (2003), Blanchflower (2000), Shepherd and Douglas (2002) are used. The mean scores of the 7 variables are assumed to be Entrepreneurial Orientation (EO). The items for EO have been codified from EO1 to EO7. Further, reliability analysis is performed to test the level of internal consistency based on Cronbach's $\alpha$ i.e. 0.863 for Entrepreneurship Education, 0.684 for Entrepreneurial Orientation and 0.772 for Perception \& Attitude. At an overall level $\alpha$ was found to be .861. Cronbach's 1951 recommended that Alpha result of .5 to .7 is acceptable while higher than .7 is considered as scale of good internal consistency, based on which the data is found to be reliable. 
Table 1. Measurement items and reliability analysis

\begin{tabular}{cl}
\hline Constructs and items \\
\hline Perception and Attitude $(\boldsymbol{P A})$ \\
PA1 & Entrepreneurship is an honorable profession. \\
PA2 & Being an entrepreneur, a person can be rich. \\
PA3 & I am a risk taker. \\
PA4 & It is too expensive to start own business. \\
PA5 & All the good idea had been taken. \\
PA6 & There are many entrepreneurial opportunity in my specific area of study. \\
PA7 & Need connection to start a business. \\
PA8 & Entrepreneurship is born not made. \\
PA9 & Entrepreneurship made not born. \\
PA10 & Entrepreneurship is living up few years like most of the people won't, so that I can spend a rest of \\
& my life most people can't. \\
PA11 & I want to be a boss. \\
PA12 & Being an entrepreneurial have a high level of status and respect. \\
PA13 & There are good opportunities for creation of new business. \\
PA14 & I know how to start and manage a small business. \\
PA15 & I believe that innovation is highly valued by entrepreneurship. \\
PA16 & It is too risky to start own business
\end{tabular}

Entrepreneurial Orientation (EO)

EO1 I am interested in Starting own business in future.

EO2 I consider self employment as very important.

EO3 I consider entrepreneurship as career options.

EO4 I didn't opt for EDP as my Major because none of my friends were taking.

EO5 My friends influenced me to opt for EDP course

EO6 Entrepreneurial education is very desirable for me.

EO7 My family wants me to take care of their business after my graduation.

Entrepreneurship Education (EE)

EE1 I enjoyed entrepreneurship education lessons

EE2 Learning entrepreneurship improved my interest in pursuing entrepreneurship as a career

EE3 The college encourage students to pursue entrepreneurship ventures

EE4 Lecturers encourages students to be innovative and creative

EE5 The college arranges seminar and programs on entrepreneurship.

EE6 The college facilitated me to come across successful entrepreneurs, which motivated me topursue entrepreneurship as a career.

EE7 With the help of entrepreneurship education, I am able to develop business plan.

EE8 With the help of entrepreneurship education, I am able to identify business opportunities.

EE9 I feel like entrepreneurship needs training.

EE10 The education in my college improves my entrepreneurial skills and abilities.

EE11 The college provides good and adequate formal training for starting up and growing new.

\subsection{Study Site}

The Study site for the present study is Gedu College of Business Studies located in the town of Gedu in Chukha Dzongkhag, Bhutan.

\subsection{Sampling Design}

A sample of 253 respondents was taken out of the total population of 738 students studying in second and third year. Krejcie \& Morgan (1970) Model of sample determination was used to arrive on the above sample size. A structured questionnaire containing closed ended questions was uploaded on google.docs to obtain the online responses. The links were shared with all the students through email, wechat, whatsapp and other digital media. The responses obtained cannot be classified under probability sampling. Thus the sampling technique used for the purpose of this study is convenient sampling.

\subsection{Instrument and Data Collection}

The data was collected through a questionnaire which had two main sections. The first one focused on measuring the demographic characteristics and the second measured the attitude of the respondents, close ended questions were designed using the Likert scale. The response scale was 5 point scale, measuring response from strongly agree to strongly disagree. The design was simple and respondents were able to answer easily. This pattern minimized any possibilities of misunderstanding of the questions or difficult interpreting the scale. 


\section{ANALYSIS AND DISCUSSION}

The data collected was processed through SPSS 21 and AMOS 20. Descriptive statistics like frequency distribution, mean, Cross Tabulation were used to analyze the demographic variables. Correlation Analysis, Regression Analysis and Structural Equation Model (SEM) were used to analyze the Entrepreneurship Education (EE), Attitude and perception (AP) and Entrepreneurial Orientation (EO). Finally Mediation analysis was performed to test the proposed model. The demography of 253 respondents is given in Table 2.

Table 2. Profile of the respondents

\begin{tabular}{llr}
\hline Descriptive Statistics & & \% \\
\hline Major & Finance & 33.6 \\
& Accounting & 27.7 \\
& HRM & 8.3 \\
& Marketing & 28.5 \\
& EDP & 2.0 \\
Parents Occupation & Own Business & 16.2 \\
& Farmers & 45.1 \\
& Corporate Employed & 2.4 \\
& Civil Servant & 23.7 \\
& Private Employed & 3.6 \\
& Others & 9.1 \\
Year & Second Year & 54.9 \\
& Third Year & 45.1 \\
Age & Under 20 & 4.0 \\
& $21-25$ & 95.3 \\
& $26-30$ & .4 \\
& Above 30 & .4 \\
Gender & Male & 43.5 \\
& Female & 56.5 \\
\hline
\end{tabular}

\subsection{Correlation Analysis}

The correlation analysis below shows the relationships between quantities variables or categorical variables. In other words, it's a measure of how constructs are related. This analysis is done to test three hypotheses i.e. $\mathrm{H}_{1}, \mathrm{H}_{2}$, and $\mathrm{H}_{3}$.

Table 3: Pearson Correlation

\begin{tabular}{cccc}
\hline & PA & EE & EO \\
\hline PA & 1 & $.498^{* * *}$ & $.584^{* * *}$ \\
EE & & 1 & $.418^{* *}$ \\
EO & & & 1
\end{tabular}

\footnotetext{
**. Correlation is significant at the 0.01 level (2-tailed). $\mathrm{N}=253$
}

As seen in the Table.3, the correlation analysis it shows that there is a positive, moderate and significant correlation between entrepreneurship education and entrepreneurial orientation, entrepreneurship education perception \& attitude, entrepreneurial orientation and perception \& attitude. The correlation analysis reveals that positive PA leads to EE. i.e. higher the perception and attitude, higher will be the chance to take up entrepreneurship education.
The results also show that PA and EO are significantly related, i.e. when Perception Attitude increases, there is increase in entrepreneurship orientation. Thirdly, it is also proven that increase in EE will lead to increase in EO significantly. This leads to accept Hypotheses, H1, H2, and $\mathrm{H} 3$

\subsection{Structural Equation Model (SEM) Analysis:}

SEM is a statistical modeling technique used to establish relationship among the variables and a confirmatory data analysis technique. The model is a classical representation of methodologies designed to exemplify the hypothesis derived from statistical summary which is deduced from the measurement of the small number of important parameters defined by the proposed underlying model. SEM is mainly used to test the propose model by way of establishing the relationship between various factors available. In this case the factors are explore through the original model and are confirmed through revised model. The important dimension for determining the same are CMIN/DF $(\chi 2 / \mathrm{df})$, whose value should be within the range of 5 . The second value is Good Fit Index (GFI) which has to be close to 1.000 . The third determined is Comparative Fit Index (CFI) which is close to 1.000; the last but not the least is Root Mean Square Error Approximation (RMESEA) it has to be close to .000 however the acceptable levels are considered at $<.08$. 
Role of Attitude and Entrepreneurship Education towards Entrepreneurial Orientation among Business Students of Bhutan

The below figures (figure 4.6, figure 4.7 and figure 4.8), shows the SEM based on Entrepreneurship Education, Entrepreneurial Orientation and Perception \& Attitude.

\subsubsection{SEM for Entrepreneurship Education}

The fit indices of revised model were as follows: GFI (Good Fit Index $)=.978$, CFI (comparative fit index $)=.997, \chi 2 / \mathrm{df}=$ $1.160, \mathrm{P}<.05$ and RMSEA (root mean square error approximation $)=.025$, indicates a good fit. The standardized beta estimates 9 items were $.599(\mathrm{p}<.01), .626(\mathrm{p}<.01)$, $.569(\mathrm{p}<.01), .532(\mathrm{p}<.01), .470(\mathrm{p}<.01), .478(\mathrm{p}<.01), .721$ $(\mathrm{p}<.01), .778(\mathrm{p}<.01), .824(\mathrm{p}<.01)$ as depicted in the figure 2.

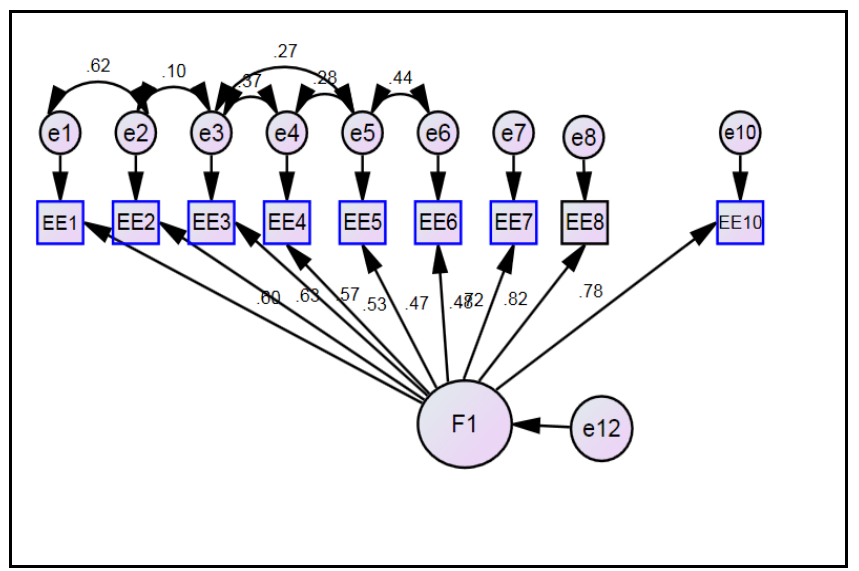

Figure 2: SEM on Entrepreneurship Education (EE)

\subsubsection{SEM for Entrepreneurial Orientation}

The fit indices of revised model were as follows: GFI (Good Fit Index $)=.988$, CFI $($ comparative fit index $)=.991, \chi 2 / \mathrm{df}=$ $1.554 \mathrm{P}<.05$ and RMSEA (root mean square error approximation $)=.047$, indicates a good fit. The standardized beta estimates 5 items were $.828(\mathrm{p}<.01) .711(\mathrm{p}<.01), .645(\mathrm{p}$ $<.01), .590(\mathrm{p}<.01), .432(\mathrm{p}<.01)$, as depicted in the figure 3 .

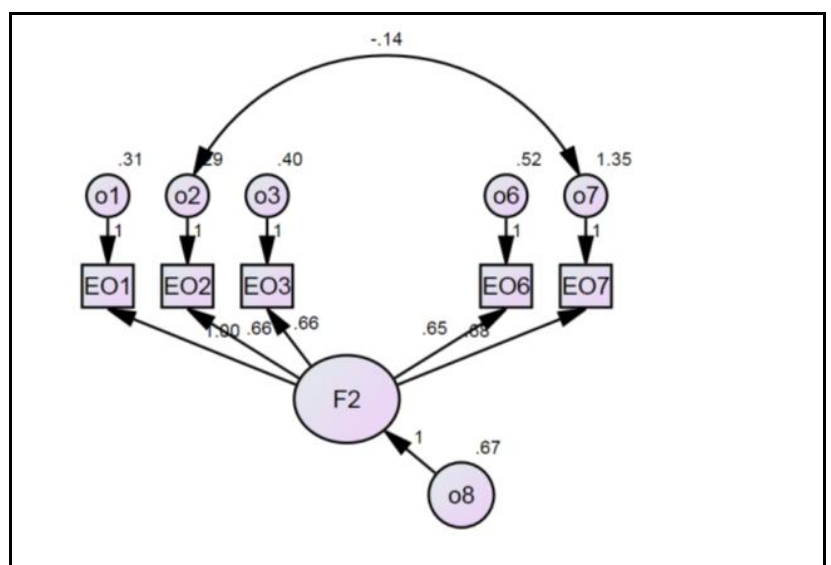

Figure 3: SEM on Entrepreneurial Orientation (EO)
The fit indices of revised model were as follows: GFI (Good Fit Index $)=.966$, CFI $($ comparative fit index $)=.986, \chi^{2} / \mathrm{df}=$ 1.210, $\mathrm{P}<.05$ and RMSEA (root mean square error approximation $)=.029$, indicates a good fit. The standardized beta estimates 12 items were $.599(\mathrm{p}<.01), .536(\mathrm{p}<.01)$, $.467(\mathrm{p}<.01), .568(\mathrm{p}<.01), .547(\mathrm{p}<.01), .235(\mathrm{p}<.01), .491$ $(\mathrm{p}<.01), .403(\mathrm{p}<.01), .597(\mathrm{p}<.01), .502(\mathrm{p}<.01), .761(\mathrm{p}$ $<.01), .635(\mathrm{p}<.01)$, as depicted in the figure 4 .

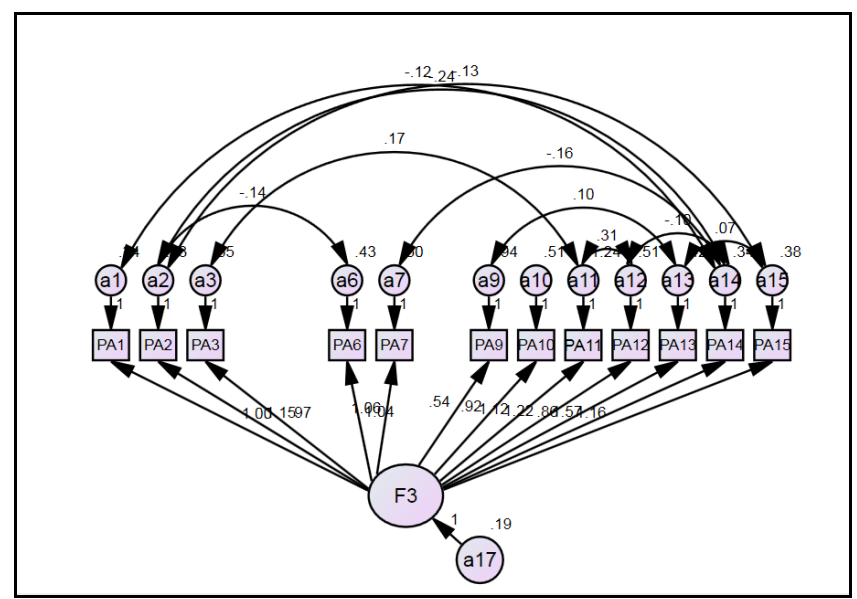

Figure 4: SEM on Perception \& Attitude

\subsection{Direct and Mediation Analysis}

In order to test the research model proposed in Chapter 3, mediation analysis has been done to test the behavior of factors. In this the first analysis is mediation analysis without mediator i.e. direct relationship between Perception and Attitude and Entrepreneur Orientation. The second analysis has been conducted to check the mediation role of education.

\subsubsection{Mediation Analysis (without mediator)}

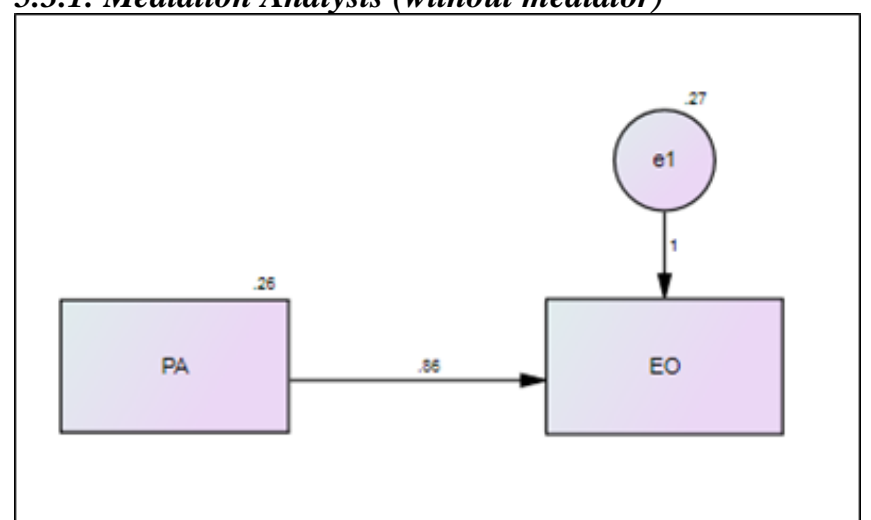

Figure 5: Path Diagram Direct Relationship between PA \& EO(Without Mediator)

\subsubsection{SEM for Entrepreneurial Perception \& Attitude}

Table 4: Regression Estimates of the Proposed Model (Without Mediator)

\begin{tabular}{|c|c|c|c|c|c|}
\hline Variables & Direction & Variable & Estimate & $\mathbf{C R}$ & $\mathbf{P}$ \\
\hline $\begin{array}{c}\text { Entrepreneurial } \\
\text { Orientation }\end{array}$ & $<---$ & $\begin{array}{c}\text { Perception \& } \\
\text { Attitude }\end{array}$ & .857 & 13.405 & $* * *$ \\
\hline \multicolumn{6}{|c|}{$* * *$ significant at $\mathrm{p}<.01$} \\
\hline
\end{tabular}


There is significant direct relationship i.e. EO <--- PA according to the table 4 . This suggests that there is direct relationship between Perception-Attitude and Entrepreneurship Orientation with a regression weight of .857. This lead to accept Hypothesis $\mathrm{H}_{4}$.

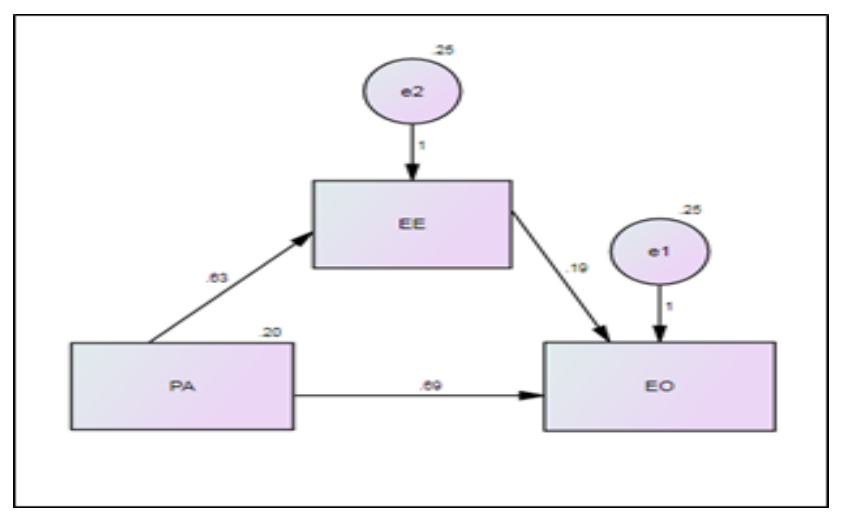

Figure 6: Path Diagram Relationship between Perception and Attitude\& Entrepreneurial Orientation - (With Mediator Entrepreneurship Education)

Table 5: Regression Estimates of the Proposed Model (With Mediator)

\begin{tabular}{|c|c|c|c|c|c|}
\hline Variables & Direction & Variable & Estimate & CR & $\mathbf{P}$ \\
\hline $\begin{array}{c}\text { Entrepreneurship } \\
\text { Education }\end{array}$ & $<---$ & $\begin{array}{c}\text { Perception \& } \\
\text { Attitude }\end{array}$ & .632 & 9.122 & $* * *$ \\
\hline $\begin{array}{l}\text { Entrepreneurial } \\
\text { Orientation }\end{array}$ & $<---$ & $\begin{array}{c}\text { Perception \& } \\
\text { Attitude }\end{array}$ & .688 & 8.606 & $* * *$ \\
\hline $\begin{array}{c}\text { Entrepreneurial } \\
\text { Orientation }\end{array}$ & $<---$ & $\begin{array}{l}\text { Entrepreneurship } \\
\text { Education }\end{array}$ & .185. & 2.940 & .003 \\
\hline
\end{tabular}

The Critical Ratio and value of $p$ illustrates the significant relationship between PA and EO; PA and EE, and EE and EO. This is the case of partial mediation on the part of EE. This suggests that Entrepreneurship Education plays a partial role in the adoption of Entrepreneurship as a career, but is not a key influencer. Key role is played by the perception and attitude in orienting the individuals to take up entrepreneurship as a career.

\section{Conclusions}

The study was conducted to see the attitude and perception of GCBS students towards Entrepreneurship education. For this purpose firstly mean analysis was done. The mean analysis signifies that the attitude and perception is positive as most of the responses given that the students were towards the agreement. It has more orientation towards agreement side which says that at the overall level it is positive. At the same time to test it minutely we have put correlation analysis and regression analysis and in both the cases it is seen that there is significant level have been found i.e. through correlation analysis it is seen that perception and attitude has a significant relation to Entrepreneurship orientation at the 0.01 level (2-tailed).

Further through SEM analysis it was identified that the impact was significant in terms perception and attitude on Entrepreneurship orientation with $\mathrm{p}$ value of .000.And then through mediation analysis it was found there was a significant effect of perception and attitude towards Entrepreneurship orientation.

Many literatures support and had proven that Entrepreneurship education has a positive influence on the Entrepreneurship orientation. "Entrepreneurship education is indeed a critical resource for whole life education.
Education can prepare for new venture initiation by transferring knowledge and developing relevant skills that improve the self-efficacy and effectiveness of the potential entrepreneur (Gorman et al., 1997)."

The correlations analysis suggests that there is a positive and significant correlation between Entrepreneurship education and Entrepreneurial orientation. The level of correlation however was moderate.

The regression analysis suggests about a significant impact of Entrepreneurial education on Entrepreneurial Orientation. However, when the same were tested through mediation analysis by considering Entrepreneurship Education as mediator, it was found to be a case of no mediation. But considering the value of $\mathrm{p}$ obtained in the analysis .003, that role cannot be discarded. To conclude it can be said that Entrepreneurship education plays a role in the Entrepreneurial Orientation and its role cannot be ignored. But, at an overall level, the perceptions and attitude were found more dominant in influencing the individual in opting entrepreneurship as a career.

\section{MANAGERIAL IMPLICATIONS}

It was identified through the study that Perception and Attitude plays a significant role not only to take entrepreneurship as a career but also a consideration for Entrepreneurship Education. The recommendations made to Educational Institutions are mainly to work on the Perception and Attitude of individual students. Institutions should put major focus on student's perception and attitude. This can be done through orientation sessions, motivation sessions, entrepreneurship student interaction, sharing success stories of existing entrepreneur etc. this is expected to influence their perception and attitude that can 
be molded towards entrepreneurship programs. A realization of shrinking job market can lead to influence their orientation from job seeker to job creator. The college should think towards development of entrepreneurial skills by way of incubation centre, simulation sessions and a more proactive entrepreneurship development cell. Liaison with the industry for better entrepreneur interface is needed to be developed at the institutional level.

\section{DIRECTION FOR FUTURE RESEARCH}

There are colleges in Bhutan which are involved in Business Education. It can be suggested to conduct a study on the attitude of students in these three colleges namely, Royal Thimphu College, Norbuling Rigter College and Gedu College of Business Studies. This study can be comparative as well as conclusive. Qualitative analysis based on focused group interview can be considered to check the observation s of key policy makers from educational institutes, government, allied agencies and NGOs in the arena of entrepreneurship. Entrepreneurship being very important aspect of economic development a nationwide study is proposed so as to cater to the entrepreneurship education at a macro level. This model can be tested in other countries where the population is different from Bhutan in terms of belief and perceptions.

\section{REFERENCES}

1. Ajzen, I (1985). From intentions to actions: A theory of planned behavior. In J. Kuhl \& J. Beckmann (Eds.), Action -Control: From cognition to behavior (pp. 11-39).Heidelberg: Springer.

2. Ajzen, I.(1991) The theory of planned behavior. Organizational behavior and human decision processes, 50(2),179-211.

3. Ajzen,I \& Fishbein,M. (1980). Understanding attitudes and predicting social behavior. Eaglewood Cliffs, NJ: Prentice Hall.

4. Arbuckle, J. L. (2006). Amos 7.0 User's Guide. PA, USA.

5. Bechard, J.P.\& Toulouse, J.P. (1998). Validation of a didactic model for the analysis of training objectives in entrepreneurship. Journal of Business Venturing. 13(4), 317-332

6. Blanchflower, D.G. (2000). Self-employment in OECD countries. Labour Economics. 7. 471-505

7. Bosma, N., \& Amoros, J. E. (2013). GEM Global Entrepreneurship Monitor, 2013 Global Report. Global Entrepreneurship Research Association (GERA).

8. Cooney, T. M. (2012, November). Entrepreneurship skills for growth-orientated businesses. In Report for the Workshop on 'Skills Development for SMEs and Entrepreneurship (Vol. 28).

9. Cronbach, L. J. (1951). Coefficient Alpha and the internal structure of tests. Psychometrica, 16(3), 297-334.

10. Douglas, E., \& Shepherd, D. (2002). Self-employment as a Career Choice: Attitudes, Entrepreneurial Intentions, and Utility Maximization. Entrepreneurial Theory and Practice. 26(3):pp. 81-90.

11. Eurydice. (2016). Entrepreneurship Education at School in Europe: Eurydice Report. Publications Office of the European Union.

12. Fayolle, A., \& Gailly, B. (2005). Using the theory of planned behaviour to assess entrepreneurship teaching programmes. Center for Research in Change, Innovation and Strategy of Louvain School of Management, Working Paper, 5, 2005.

13. Gorman, G., Hanlon, D., \& King, W. (1997). Some research perspectives on entrepreneurship education, enterprise education and education for small business management: a ten-year literature review. International Small Business Journal. 15(3), 56-79

14. Hair, J. F, Jr. Anderson, R. E, Tatham, R. L, \&amp; Black, W. C. (1998). Multivariate data analysis (5 th Ed.). Upper Saddle River, NJ: Prentice Hall.

15. Hisrich, R. D. with Michael P. Peters and Dean A Shepherd, 2008, Entrepreneurship.

16. Impson, R. D., \& Steve Oliver, J. (1990). A summary of major influences on attitude toward and achievement in science among adolescent students. Science education, 74(1), 1-18.
17. Katz, J. A. (2003). The chronology and intellectual trajectory of American entrepreneurship education: 1876-1999. Journal of business venturing, 18(2), 283-300.

18. Keat, O. Y., Selvarajah, C., \& Meyer, D. (2011). Inclination towards entrepreneurship among university students: An empirical study of Malaysian university students. International Journal of Business and Social Science, 2(4).

19. Kolvereid, L. (1996). Prediction of Employment Status Choice Intentions. Entrepreneurship Theory and Practice, 21(1), 47-58. https://doi.org/10.1177/104225879602100104

20. Krejcie, R.V., \& Morgan, D.W. (1970). Determining Sample Size for ResearchActivities. Educational and Psychological Measurement, 30, 607-610

21. Kuralic, A. (2014). Propensity and motive behind the choice of Self-Employment: in rural and urban Sweden.

22. Kuratko, D. F., \& Hodgetts, R. M. (2004). Entrepreneurship: Theory, Process. Practice, 6.

23. Peterman, N. E., \& Kennedy, J. (2003). Enterprise education: Influencing students' perceptions of entrepreneurship. Entrepreneurship theory and practice, 28(2), 129-144.

24. Pulka, B. M., Rikwentishe, R., Mani, U. A. U., \& Jossiah, M. M. (2015). Variation of Attitude among University Students towards Entrepreneurship Education. Journal of Business Administration and Education, 7(2).

25. Roberts, R.C. (1986). Faith, Reasons and History. Mercer Publication. Georgia

26. Rudhumbu, N., Svotwa, D., Munyanyiwa, T., \& Mutsau, M. (2016). Attitudes of Students towards Entrepreneurship Education at Two Selected Higher Education Institutions in Botswana: A Critical Analysis and Reflection. Academic Journal of Interdisciplinary Studies, 5(2), 83.

27. Shane, S., \& Venkataraman, S. (2000). The promise of entrepreneurship as a field of research. Academy of management review, 25(1), 217-226.

28. Shephered D. A., \& Wiklund, J. (2003) Knowledge-Based Resources, Entrepreneurial Orientation, and the Performance of Small and Medium-Sized Business. Strategic Management Journal 24(13):1307 1314

29. Simpson, R. D., \& Oliver, J. S. (1990). A summary of the major influences on attitude toward and achievement in science among adolescent students. Science Education. 74, 1-18.

30. Utha, K., Rinchen, S., Gurung, B., Gurung, G., Rabgay, T., \& Dorji, C. (2016). Entrepreneurship Education in Bhutan: Perception, Culture and Challenges. World Journal of Educational Research, 3(2), 460.

31. Vesper, K.H. (1983). Entrepreneurship and National Policy. Heller Institute. Massachusetts, USA

32. Vesper, K.H. (1990) New Venture Strategies, Prentice-Hall, Englewood Cliffs, N.J.

33. Vesper, K.H., \& McMullan, W.E. (1988), Entrepreneurship: Today courses, tomorrow degrees?, Entrepreneurship Theory \& Practice, 13(1), $7-13$.

34. Von Graevenitz, G., Harhoff, D., \& Weber, R. (2010). The effects of entrepreneurship education. Journal of Economic Behavior \& Organization, 76(1), 90-112.

35. Wang, C. K., \& Wong, P. K. (2004). Entrepreneurial interest of university students in Singapore. Technovation, 24(2), 163-172.

36. Wiklund, J., \& Shepherd, D. (2003). Knowledge-based resources, entrepreneurial orientation, and the performance of small and medium-sized businesses. Strategic management journal, 24(13), 1307-1314. 